\title{
電量滴定法による金属およびガラス表面の水分， ならびにベリリウム中の水素の定量
}

\author{
吉森 孝良* 石 割 修一** 渡辺良 雄* \\ 原田 孝* 山田正二*
}

Takayoshi Yoshimori, Shuiti Ishiwari, Yoshio Watanabe, Takashi Harada and Shoji Yamada : Coulometric Microdetermination of Surface Water on Metals or Glasses and of Hydrogen in Beryllium. Water absorbed on the surface of a sample was determined by the carrier gas extraction followed by the coulometric titration method (ref.3,4). The water was extracted from a heated sample into argon, and was transferred to $\mathrm{NH}_{3}$ with $\mathrm{NaNH}_{2}$. The $\mathrm{NH}_{3}$ was titrated with the electrolytically generated $\mathrm{BrO}^{-}$ion.

The absorbed water on the surfaces of steels differed depending on the roughness of the surfaces. The amounts of it on the filed and electropolished samples were $0.5 \sim 0.7 \mu \mathrm{g} / \mathrm{cm}^{2}$ and $0.2 \sim 0.3 \mu \mathrm{g} / \mathrm{cm}^{2}$ respectively. These results show that the disturbance of the surface water on the sample is almost negligible in the determination of hydrogen in steel. Fractional determination of the surface water and hydrogen in a stainless steel was also possible. The water was first determined by heating the sample at $100^{\circ} \sim 120^{\circ} \mathrm{C}$, hydrogen in the sample was extracted at $1100^{\circ} \mathrm{C}$, and then determined after oxidation to water.

Hydrogen in beryllium was extracted into argon by heating the sample at $1100^{\circ} \mathrm{C}$ and determined by the same method. A sample contained $4.8 \mathrm{ppm}$ of hydrogen. The water evolved from the same metal was also determined, and a considerable amount of water $(21 \sim 23 \mathrm{ppm})$ was observed by heating the sample at $400^{\circ}$ or $800^{\circ} \mathrm{C}$.

The water evolved from glasses by heating the sample at $300^{\circ} \mathrm{C}$ was determined by this method. A soft glass evolved $4 \sim 7 \mu \mathrm{g} / \mathrm{cm}^{2}$ of water, and many hard glasses (Pyrex or others) evolved $0.2 \sim 0.3$ $\mu \mathrm{g} / \mathrm{cm}^{2}$ of it. The water on the surface of quartz was only $0.05 \sim 0.07 \mu \mathrm{g} / \mathrm{cm}^{2}$.

(Received April 24, 1971)

\section{I. 緒 言}

金属表面に生成している酸化皮膜中の水分, あるいは吸 着等によって付着している水分が, 酸素の定量結果に与兄 る影響は，すでに神森ら (1)によって検討されており，試料 の表面をヤスリで仕上げた程度でも，あまり誤差は大きく ならないことが知られている. またアルミニウムの水素を 分析するときに，その表面の処理法が，結果に大きな影響 を与えることが, 後藤らによって検討された ${ }^{(2)}$.

しかしこれらの検討においては, 試料から放出される全 酸素または全水素の定量値の增減から結論を導びいてお り, 試料から出た水分のみを定量することはまだ試みられ ていない，これは鋼等中の水素含有量が極めて少なく，ま た同時に水分定量に対する従来の方法の感度はあまり高い とはいい切れないために, 一般の水素または水分の定量法 をこの問題の解決に利用することは極めて困難なためと思 われる. またたんに試料金属中の水素を定量する場合にお いても, 全酸素の分析によって得られた試料表面の処理法

* 東京理科大学工学部 (Faculty of Engineering, Science University of Tokyo, Tokyo)

** 東京理科大学大学院, 現在 : 株式会社日立製作所 武蔵工場(Graduate School, Science University of Tokyo. Present address : Musashi Works of Hitachi, Ltd., Kodaira)
に関する結果を，そのまま利用できるかどうかを確かめて おくことは必要と思われる.

さきに著者らは，鉄鋼その他の金属中の水素の定量に， 試料を加熱して水素をアルゴン気流中に抽出したのちこれ を酸化して水に変光，さらにその水をナトリウムアミドと 反応させて，そこで発生したアンモニアを電量滴定するこ とにより，金属中の水素 (3)，あるいは天びんの分銅に付着 した水分を定量した ${ }^{(4)}$.この方法によると，たとえば鉄鋼 等を加熱してキ+リヤーガス中に水素と水の混合物が抽出 されても，ナトリウムアミドは水とだけしか反応しないか ら，ある程度高温に加熱しても水分だけを単独に定量でき る. そこでこの特長を鉄鋼試料などの表面の水分の定量に 利用し，その表面処理法による水分測定結果との関係をし らべた。 また同時に，従来測定結果の少ない金属べリリウ ム中の水素および水分を定量した。 さらにまたガラス等を 加熱するとかなりな量の水が発生することがあるが，その 程度を種々のガラスについて測定したので, それらの結果 を報告する。

（1）神森，山口, 鉿木：金属学会誌, 32 (1968)，1190.

（2）後藤, 細谷, 大高 : 金属学会誌, 29 (1965), 876.

(3) T.Yoshimori and S. Ishiwari : Talanta, 17 (1970), 349.

(4) T. Yoshimori and S. Ishiwari : Bull. Chem. Soc. Japan, 42 (1969) , 1282. 


\section{II. 実 験 方 法}

\section{1. 装置および試薬}

表面水分の定量に使用した装置の概略は Fig.1 に示し た. まずアルゴン中の水素または水素化合物(有機物と思 われる)を除去するために, 酸化銅 $\left(600^{\circ} \mathrm{C}\right)$ で酸化したのち 二酸化炭素および水分を吸収除去する，このアルゴンをさ らにスポンジチタン $\left(700^{\circ} \mathrm{C}\right)$ で精製したのち, 試料を入れ た抽出炉の石英管中に送入した．試料はボート上部のコッ ク (内径 $10 \mathrm{~mm}$ ) 部からアダプター（ロート状）を用いて投 入し, 分析後の試料は, 磁性を持つものはやはりコック I を通して磁石で引き出し，また磁性を持たない試料はコッ ク下部のスリ合わせをはずして取り出した. ただし金属試 料の場合は前回の分析後の試料がボート上に残っている上 に次の試料を加えていっても, 後で加えた試料の分析值に 影響を与えることはなかった. したがってボートをやや大 型(幅 $10 \mathrm{~mm}$ ，長さ $50 \mathrm{~mm}$ ) にし， 5 6 回連続して試料を 加えて分析したのちに，まとめて全部を取り出すこともで きる. もちろん後藤ら ${ }^{(2)}$ の装置のようにするのもよいと思 われる.

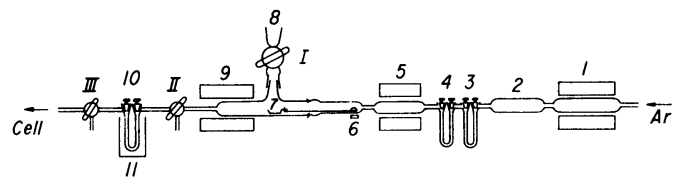

Fig.1 Apparatus for extraction of water and conversion to ammonia

$1: \mathrm{CuO}$ furnace $2: \mathrm{NaOH} 3: \mathrm{Mg}\left(\mathrm{ClO}_{4}\right)_{2} \quad 4: \mathrm{P}_{2} \mathrm{O}_{5}$

$5:$ Ti sponge $6:$ Magnet $7:$ Quartz boat

8: Sample inlet $9:$ Sample heater $10: \mathrm{NaNH}_{2}$

11 : Oil bath I-III : Cock

キャリヤーガス中の水をアンモニアに変えるナトリウム アミドは, 径約 $5 \mathrm{~mm}$, 長さ約 $10 \mathrm{~cm}$ のU字管に石英ウー ルと交互につめ, U 字管は油浴に入れて $80 \pm 0.1^{\circ} \mathrm{C}$ に保 った. 電量滴定に用いたセルおよび装置は Fig.2 に示し た. 指示電極対は径 $0.5 \mathrm{~mm}$, 長さ約 $5 \mathrm{~mm}$ の白金線を用 い, 発生極は $10 \mathrm{~mm}$ 角の白金板, 発生対極は径 $0.5 \mathrm{~mm}$, 長さ約 $50 \mathrm{~mm}$ の白金線をコイル状に巻いたものである. 隔膜はガラス沪過板 (径約 $10 \mathrm{~mm}$ ) を用いた，定電流装置 は従来とほぼ同様の真空管式のもの (5)であり, 時間の測定 は同期電動機を使用した時間計 (日本サーボ社製タイムリ ーダー)によった.

コックその他のスリ合わせ部のグリースは, Apieson L を用い，装置の電気炉中に入るところは石英製，またそれ 以外の部分はすべてパイレックスガラス製とし，連結はす ベてスリ合わせである.これらは空試験值を小さくするた めに極めて重要な注意事項である.

試薬はすべて特級品を使用し, 溶液は次の力法で作っ た. ホウ酸ナトリウム緩衝溶液 : ホウ酸ナトリウム $38.1 \mathrm{~g}$

(5) 吉森, 日野, 武内：分析化学, 15(1966)，1234.

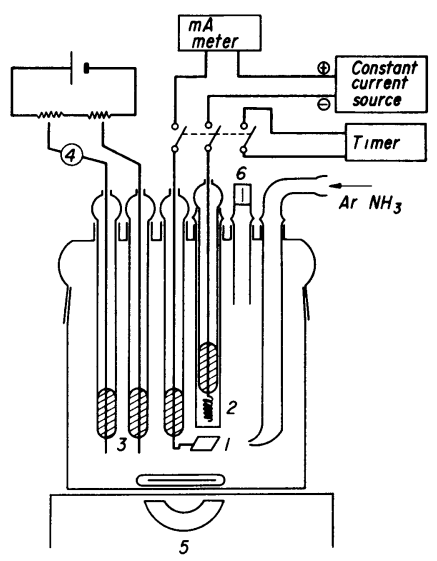

Fig.2 Cell for coulometric titration 1 : Generating electrode $2:$ Auxiliary electrode 3 : Indicator electrode pair $4: \mu \mathrm{A}$ meter

5 : Magnetic stirrer $6:$ Bunsen valve

を水 $1 \mathrm{~L}$ にとかし，過塩素酸を滴加して $\mathrm{pH} 8.6$ に調節す る. 電解液 : 臭化ナトリゥム溶液 $(5 \mathrm{M}) 25 \mathrm{~mL}$ に, 上記緩 衝溶液 $50 \mathrm{~mL}$ を加え，水で $125 \mathrm{~mL}$ にうすめて用いる.

\section{2. 実験操作}

試料の表面処理 : 試料はヤスリおよびェメリー紙などで 仕上げるほかに，酸化クロムエマルジョンを用いた鏡面仕 上げおよび電解研摩法などの種々の方法で表面を磨いたの ち，アセトンで洗浄し，さらにソックスレー抽出装置を用 いてェチルェーテルで約 30 分間洗浄したものを，デシケ 一タ一中に保存した. 電解研摩の方法は, 他の報告 ${ }^{(1)}$ に示 されたものとほぼ同様である。

装置の準備 : はじめにアルゴンを $200 \mathrm{~mL} / \mathrm{min}$ の速さで 流しながら Fig.1 の電気炉 1 を加熱し，つぎに脱水剂等の 入ったU字管部を除く全ガラス部を，スリ合せ部もとも に, フレキシブルヒーターで約 $110^{\circ} \mathrm{C}$ に加熱する. 同時に 電気炉 5 および 9 女加熱しはじめ, また定電流装置のスイ ッチを入れる. このときのアルゴンはコック IIから放出す る. 電気炉がほぼ所定の温度に近ついたところで油浴の温 度を約 $110^{\circ} \mathrm{C}$ とし、コック IIおよびIIIを操作して，アルゴ ンをナトリウムアミドのU字管を通したのち、コックIIIか ら放出する.この状態を約 30 分間保ったのち, 油浴の温 度を $80 \pm 0.1^{\circ} \mathrm{C}$ まで下げ, 電解液を入れた電解セルを連

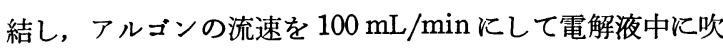
き込む. また電解セルの指示電極間に, 加電圧装置を用い て $0.2 \mathrm{~V}$ の電圧を加え, フレキシブルヒーターをとりはず 于.

空試験值の測定 : セル中の電解液を $2 \sim 5 \mathrm{~mA}$ の間の一 定電流で電解酸化し, 指示回路の $\mu \mathrm{A}$ 計に $0.4 \mu \mathrm{A}$ 程度の 電流が流れるに至らせる。ち」らど 5 分間後にふたたび電 解をはじめ, 指示電流が前の值 $(0.4 \mu \mathrm{A})$ に上昇するまで 定電流電解を行ない, 電解時間と電解電流を測定する. こ の 5 分間ごとの電解を, 電解時間が一定值になるまで繰り 
返し，これを 5 分間あたりの空試験值とする.ふつうこの 空試験值は数十分間後に一定になるが，これが一定になり にくかったり，またアルゴンの精製が完全であるのに空試 験值が增大したとき，あるいは逆に極めて小さくなった場 合は,ナトリウムアミドが劣化したのであるから，これを 新しいものと取りかえる. ふつらナトリウムアミドは数十 回の使用に耐える。

試料表面の水分の測定：あらかじめ精ひょらし，デシケ 一ター中に保存しておいた試料を, 足が太くて長いロート をアダプターに使用してコック Iからボート上に落し，磁 石を操作してボートを所定温度の電気炬内にそう入する。 ボート上への試料そう入の操作は，30 秒間以内にすをせ ば，大気中の水蒸気の影響は認められなかった。つぎに空 試験のときと同じ操作で， 5 分間ごとに電解液に吸収され たアンモニアを定量する．20３0 分間後に，試料を入れ たボートを炉の加熱部から一たんコックIの付近まで引き 出し, 電解時間を湘定したのちふたたびボートを高温部へ そう入して加熱し，水の放出が完全かどらかを確かめると よい，電解時間が空試験のときと一致したところで実験を 終了する.

水素の定量：金属中の水素は, Fig.1 の電気炉 9 とコッ ク II のの間に，酸化銅をつめた反応管を入れて，これを電 気炉で $600^{\circ} \mathrm{C}$ に加熱して水素を水に酸化すれば定量でき る. 定量の操作はさきの水分の定量のときと同じである.

\section{III. 実験結果と考察}

\section{1. ステンレス鋼試料の分析}

はじめに水素含有量の变化が少ないといわれるステンレ 鋼試料 $(20.0 \% \mathrm{Cr}, 10.5 \% \mathrm{Ni})$ について検討した。 また この場合には III.2.の最後にのべたように水素抽出炉の次 に酸化銅をつめた電気炉を入れてある水素定量用装置を利 用し， 最初に試料を抽出炉の入口近くのところで $100^{\circ} \sim$ $120^{\circ} \mathrm{C}$ に加熱してまず表面の水分だけを放出させて定量 し, 次河料を $1100^{\circ} \mathrm{C}$ に加熱して, 発生した水素を定量 する方法によって, 表面の水と試料内部の水素の分別定量 を行なった。 その結果は Table 1 亿示した.
Table 1 の結果から明らかなように, 試料表面の平滑度 が增すにつれて吸着している水分は減少している。しかし その量はもともと少ないものであり，また減少の程度もわ ずかであるから，これら吸着水が水素の定量結果に与える 影響は，きわめてわずかである，さきに神森らが，酸素を 分析して本研究と同様の検討をしたときに(1)，多くの鋼試 料においてはヤスリ仕上げのときも電解研摩などの仕上げ を行なっても，あまり差がなかったといら結果を得ている が, Table 1 の結果はそれを裏書きしたものといえよう.

以上の実験結果における多少の問題点として, 試料を最 初に約 $100^{\circ} \mathrm{C}$ に加熱したとき，表面の水分とともに内部の 水素も幾分抽出される抢それがあることと，も5一つは表 面に酸化皮膜が生成しているとき，それと結合した水が $100^{\circ} \mathrm{C}$ 程度では完全に抽出されないのではないかといら点 が考えられる，それでこれらのことを確かめるために，装 置を本来の Fig.1のと扣りにして, 水素は定量されないよ

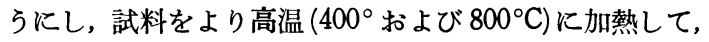
発生した水分だけを定量した結果を Table 2 に示した。

Table 2 Determination of the water on the surfaces of the stainless steel

\begin{tabular}{c|c|c|c|c}
\hline $\begin{array}{c}\text { Surface } \\
\text { treatment }\end{array}$ & $\begin{array}{c}\text { Heating } \\
\text { temperature } \\
\left({ }^{\circ} \mathrm{C}\right)\end{array}$ & $\begin{array}{c}\text { No. of } \\
\text { determi- } \\
\text { nations }\end{array}$ & $\begin{array}{c}\text { Water } \\
\text { on the } \\
\text { surface } \\
\left(\mu \mathrm{g} / \mathrm{cm}^{2}\right)\end{array}$ & $\hat{\boldsymbol{\sigma}}$ \\
\hline Filing \{ & 800 & 5 & 0.80 & 0.09 \\
Electropolishing & 400 & 5 & 0.57 & 0.21 \\
\hline
\end{tabular}

この表の実験結果は, Table 1 のそれぞれ同じ仕上げを したものについて得たと比較して，あまり差があるとはい えない，したがって上述のような問題点は，ステンレス鋼 試料においては，ほとんど考慮しなくてもよいと思われ る.

試料加熱温度をより高く， $800^{\circ} \mathrm{C}$ にしたときは，やや高 值を得ているが，これは試料中の酸素と水素とが反応し て，水として放出されたためではないかとも考えられる. しかしその差はわずかであり，明確な結論を出すことはで

Table 1 Fractional determination of the hydrogen in a stainless steel and the water on its surface (Sample : $10.5 \% \mathrm{Ni}, 20.0 \% \mathrm{Cr}$ )

\begin{tabular}{|c|c|c|c|c|c|}
\hline \multirow{2}{*}{ Surface treatment } & \multirow{2}{*}{$\begin{array}{c}\text { No: of } \\
\text { determinations }\end{array}$} & \multirow{2}{*}{$\begin{array}{l}\text { Water on the } \\
\text { surface } \\
\left(\mu \mathrm{g} / \mathrm{cm}^{2}\right)\end{array}$} & \multirow{2}{*}{$\begin{array}{l}\text { Hydrogen in } \\
\text { the sample } \\
(\mathrm{ppm})\end{array}$} & \multicolumn{2}{|c|}{ Total hydrogen } \\
\hline & & & & $(\mathrm{ppm})$ & $\hat{\sigma}$ \\
\hline $\begin{array}{c}\text { Filing }\{ \\
\text { Emery paper }\left\{\begin{array}{l}\mathrm{No} .320 \\
\mathrm{No} .1000\end{array}\right. \\
\text { Buff with } \mathrm{Cr}_{2} \mathrm{O}_{3} \\
\text { Electropolishing }\end{array}$ & $\begin{array}{l}4 \text { (c) } \\
55^{(c)} \\
2 \\
2 \\
3 \\
5\end{array}$ & $\begin{array}{l}0.55 \\
0.71 \\
0.52 \\
0.47 \\
0.40 \\
0.30\end{array}$ & $\begin{array}{l}3.86 \\
3.81 \\
3.84 \\
3.66 \\
3.62 \\
3.84\end{array}$ & $\begin{array}{l}3.94 \\
3.93 \\
3.92 \\
3.73 \\
3.68 \\
3.89\end{array}$ & $\begin{array}{l}0.15 \\
0.09 \\
0.06 \\
0.09 \\
0.13 \\
0.11\end{array}$ \\
\hline
\end{tabular}

(a) : The water was extracted by heating the sample at $100^{\circ} \sim 120^{\circ} \mathrm{C}$, and the results were calculated from the apparent surface area

(b) : The sample was heated at $1100^{\circ} \mathrm{C}$ after the determination of the water

(c) : Analyzed by different analysts 
きなかった。

いずれ亿せよステンレス鋼試料の表面吸着水は, $1 \mu \mathrm{g} /$ $\mathrm{cm}^{2}$ をこえることはなく，しか子水素に換算すればさらに その $1 / 9$ になるから，とくに手数をかけて試料表面を研摩 する操作は，一般には必要ないとしてよいであろう。

\section{2. 炭素鋼試料表面の水の定量}

次に炭素鋼を試料として, Table 2 のときと同様の方法 で表面の水分を定量した，その結果を Table 3 亿示す。

Table 3 Determination of the water on the filed surface of a carbon steel (Sample ; C : $0.07 \%$, Si : $0.01 \%$, Mn : $0.52 \%)$

\begin{tabular}{c|c|c}
\hline Heating temperature & \multicolumn{2}{|c}{ Water found $\left(\mu \mathrm{g} / \mathrm{cm}^{2}\right)$} \\
\cline { 2 - 2 }$\left({ }^{\circ} \mathrm{C}\right)$ & Mean ${ }^{(\mathbf{a})}$ & $\hat{\sigma}$ \\
800 & 0.53 & 0.16 \\
400 & 0.41 & 0.03 \\
\hline
\end{tabular}

(a) : Mean value of 4 determinations

この結果から明らかなように，炭素鋼においてもその表 面の吸着水はステンレス鋼の場合と大差はなかった。 また 抽出温度を高くした場合にも同様にやや高値を与之る傾向 がみられた

いずれにせよ Table 1～3に示した実験結果は，さきに 報告した ${ }^{(4)}$ 板状分銅の表面吸着水の測定結果と同程度の值 であり，金属表面の吸着水の量は，多くの場合この程度と 考えてよい上うに思われる.

なお実験結果は省略するが，炭素鋼の表面を電解研摩し た場合には，研摩後の水洗や乾燥等の処理中にさびが発生 して，異常な高值を与えることがしばしばあった。したが って古谷ら ${ }^{(6)}$ のようにとくに高純度試料を扱ら場合はとも かく，一般のさびやすい試料においては，電解研摩などの 方法によらず，たんにヤスリで仕上げる程度にしておいた ほうが，かえって安全であるといえる。

\section{3. 金属ベリリウム中の水素および水の定量}

金属ヘリリウムに含まれている水素の定量例はあまり見 当らないので，これについて検討した，すなわち Fig.1の 装置に执いて，試料加熱师とナトリウムアミドを入れたU 字管との間に酸化銅反応管(電気炬で $600^{\circ} \mathrm{C}$ に加熱)を入 れ，試料の加熱により発生した水素を水にかえたのち，本 法で定量した．また Fig.1の装置をそのまま用いて，金属 ベリリウムを $100^{\circ} \mathrm{C}$ なし $800^{\circ} \mathrm{C}$ に加熱したとき発生 する水分を定量した，それらの結果を Table 4 亿示す。

このようにべリリウム中(またはその表面)には，他の金 属に比較して，多量の水分が存在しており，しかもそれは 多少の加熱によって比較的容易に放出されるようである. ここで使用した試料は，棒状の材料から切りとったのちテ セトンで洗浄したものである．また試料をさらに高温に加

（6）古谷，菊地，鎌田：分析化学, 17(1968)，770.
Table 4 Determination of the hydrogen and the water in a beryllium metal

\begin{tabular}{c|c|c|c}
\hline $\begin{array}{c}\text { Heating } \\
\text { temp. } \\
\left({ }^{\circ} \mathrm{C}\right)\end{array}$ & $\begin{array}{c}\text { No. of } \\
\text { determi- } \\
\text { nations }\end{array}$ & $\begin{array}{c}\text { Water found } \\
(\mathrm{ppm})\end{array}$ & $\begin{array}{c}\text { Total } \\
\text { hydrogen } \\
\text { found (ppm) }\end{array}$ \\
\hline 1100 & 5 & - & 4.83 \\
100 & 3 & 9.4 & - \\
200 & 2 & 15.8 & - \\
400 & 1 & 20.1 & - \\
800 & 2 & 23.3 & - \\
\hline
\end{tabular}

熱すれば, 水素の定量結果もより大きくなるかも知れ ないが, 装置のつごうでこれ以上の検討は行なわなかっ た.

いずれにしても金属ベリリウム中またはその表面には， 他の金属の表面に吸着されている水分に比較して，異常に 多くの水分が存在していると考吕られる.

\section{4. 加熱したガラスが放出する水分の定量}

真空装置等に使用寸るガラスは，なるべく高級なものか あるいは石英ガラスなどがよく用いられる。このよらなガ ラスを用いた場合に，実際にどの程度の水が放出されるも のかを測定した.すなわち試料は種々のガラス管を約 $1 \mathrm{~cm}$ の長さに切り,クロム硫酸中に一夜間浸せきしたのち水洗 した．これをさらに $110^{\circ} \mathrm{C}$ で約 3 時間加熱乾燥してから， 室温 $\left(20^{\circ} \sim 25^{\circ} \mathrm{C}\right)$ に保った臭化ナトリウムなどの溶液を入 れたデシケーター中に，24 時間保存したものを用いた。試 料加熱温度は $300^{\circ} \mathrm{C}$ とたが，この温度でガラス中の結 合水が全部放出されるとは考えられない，しかし実際にガ ラス管等を各種装置に用いたときは，この程度の温度以上 に加熱する場合が比較的少ないことと，比較のために一定 温度をとる必要があったためにこの温度を採用した。

実験結果は Table 5 に示したとおりで，並ガラスはこの

Table 5 Determination of the water evolved from various glasses by heating at $300^{\circ} \mathrm{C}$

\begin{tabular}{c|c|c}
\hline Kind of glass & $\begin{array}{c}\text { Relative humidity* } \\
(\%)\end{array}$ & $\begin{array}{c}\text { Water found } \\
\left(\mu \mathrm{g} / \mathrm{cm}^{2}\right)\end{array}$ \\
\hline Quartz & 53 & 0.03 \\
Hard glass & 68 & 0.05 \\
\hline Pyrex & 53 & 0.16 \\
\hline Soft glass & 53 & 0.19 \\
\hline Vycol glass & 58 & 0.20 \\
\hline Heatron T** & 58 & 0.24 \\
\hline Heatron $W^{* *}$ & 58 & 7.1 \\
\hline
\end{tabular}

* Approximate values

** Produced by Fuji Film Co. 
程度の温度で 4 7 $\mu \mathrm{g} / \mathrm{cm}^{2}$ の水分を放出するのに対して, JIS 1 級程度の硬質ガラスやハイレックスガラスの水分放 出量はそれよりも一桁少なく，石英ガラスはさらに一桁 少なく，従来の文献值ともかなりよく合った結果を得 た (7) (8).

ガラス中の水分は，表面吸着水として存在するよりも， もしろ結合水として存在している場合が多い上らである

(7) I. M. Kolthoff and E. B. Sandell : Textbook of Quantitatıve Inorganic Analysis, 3 rd. Ed., p.144, Macmillan-Maruzen (1964) .

(8) K.R.Lange : J.Colloid Sci., 20 (1965), 231.
が，Table 5 の笑験結果から茪て，この程度の温度ではパ イレックスガラス級の硬質ガラスからは，㭱とんど表面の 吸着水程度の水が放出されるにすざない，したがって電気 炬で加熱される部分虫石英ガラスを用い，常温付近で使用 する部分はパイレックスガラス製としたFig.1の装置の構 成は，一応妥当なものとい方よう。

むちろんこの央験では加熱温度が低いため，ガラス中の 結合水などがすべて定量できたものとはいえない，しかし これらの結梁は実際に各種の装置等を組みたてるよらな場 合に，有用な知見を与党るもの上考党る 